Continuing infection is suggested as the cause by the isolation of spirochetes from cerebrospinal and synovial fluid, ${ }^{1525}$ the identification of spirochetes in synovium ${ }^{24}$ and myocardial tissues, ${ }^{21}$ and successful treatment of neurological ${ }^{29}$ and arthritic disease with high dose intravenous penicillin. ${ }^{30}$ Generally the yield of positive cultures has been very low: Steere et al investigated 118 patients, and only four specimens yielded spirochetes-23 specimens of joint fluid synovium and cartilage all gave negative results. ${ }^{31}$

Early treatment with antibiotics (tetracycline or penicillin) stops the disease's course. ${ }^{32} 33$ For adults the treatment is tetracycline ( $250 \mathrm{mg}$ four times daily for 10 days) and for children phenoxymethylpenicillin $(50 \mathrm{mg} / \mathrm{kg}$ daily in divided doses). None of 39 patients treated with tetracycline developed late complications of the disease compared with $8 \%$ of those given penicillin and $14 \%$ given erythromycin. ${ }^{33}$

Here in Connecticut the spirochete is progressing relentlessly up the Connecticut River valley into the heart of the state. In 1985 the state health laboratory recorded 863 new cases, and those of us in practice here see more cases each year. The rapid reporting of four cases in Britain shows that Lyme disease has now arrived in old England, too, and the disease may spread just as relentlessly.

ANN PARKe

Assistant Professor,

Division of Rheumatology,

University of Connecticut,

Farmington,

Connecticut 06032-9984,

USA

1 Steere AC, Malawista SE. Cases of Lyme disease in the United States: locations correlated with the distribution of Ixodes dammini. Ann Intern Med 1979;91:730-3.

2 Centers for Disease Control. Lyme disease. MMWR 1982;31:367-8.

3 Ackermann R, Runne U, Klenk W, et al. Erythema chronicum migrans mit Arthritis. Disch Med Wochenschr 1980;105:1779-81.

4 Illouz G, Hewitt J. A propos de l'athrite de Lyme: polyarthrite inflammatoire après un erythème annulaire migrant. Revue du Rheumatisme 1981;48:813-5.

5 Stewart A, Glass J, Patal A, Watt G, Cripps A, Clancy R. Lyme arthritis in the Hunter Valley. Med F Aust 1982; ;: 139 .

6 Johnson RC, Schmid GP, Hyde FW, Steigerwalt AG, Brenner DJ. Barrelia burgdorferi sp nov: etiologic agent of Lyme disease. International fournal of Systemic Bacteriology 1984;34:496-7.

7 Steere AC, Broderick TE, Malawista SE. Erythema chronicum migrans and Lyme arthritis: epidemiologic evidence for a tick vector. Am J Epidemiol 1978;108:312-21.

8 Wallis RC, Brown SE, Kloter KO, et al. Erythema chronicum migrans and Lyme arthritis: field study of ticks. Am J Epidemiol 1978;108:322-7.

9 Burgdorfer W, Kierans JE. Ticks and Lyme disease in the United States. Ann Intern Med 1983;99:121.

10. Barbour AG, Burgdorfer W, Hayes SF, Peter O, Aeschlimann A. Isolation of cultivable spirochete from Ixodes ricinus ticks of Switzerland. Current Microbiology 1983;8:123-6.

11 Steere AC, Bartenhagen NH, Craft JE, et al. The early clinical manifestations of Lyme disease. Ann Intern Med 1983;99:76-82.

12 Reik L Jr, Burgdorfer W, Donaldson JO. Nuerological abnormalities in Lyme disease without erythema chronicum migrans. Am $\mathcal{F}$ Med 1986;81:73-8.

13 Pachner AR, Steere AC. Neurological findings of Lyme disease. Yale J Biol Med 1984;57:481-3.

14 Pachener AR, Steere AC. The triad of neurological manifestations of Lyme disease: meningitis, cranial neuritis, and radiculoneuritis. Neurology $(N Y)$ 1985;35:47-53.

15 Reik L, Steere AC, Bartenhagen NH, Shope RE, Malawista SE. Neurological abnormalities of Lyme disease. Medicine (Baltimore) 1979;58:281-94.

16 Steere AC, Grodzicki RL, Kornblatt AN, et al. The spirochetal etiology of Lyme disease. N Englf Med 1983;308:733-40

17 Williams D, Rolles CJ, White JE. Lyme disease in a Hampshire child-medical curiosity or beginning of an epidemic. BrMed f 1986;292:1560-1.

18 Bannwarth A. Chronische lymphozytare Meningitis, entzündiche Polyneuritis und Rheumatismus. Archiv für Psychiatrie und Nervenkrankheiten 1941;113:284-376.

19 Garin CH, Bujadoux. Paralysie par les tique. Journal de Medecine de Lyon 1922;71:765-7.

20 Steere AC, Malawista SE. Lyme disease. In: Kelly WN, Harris ED Jr, Ruddy S, eds. Textbook of rheumatology. Philadelphia: W B Saunders, 1985:1557-63.

21 Marcus LC, Steere AC, Duray PH, Anderson AE, Mahoney EB. Fatal pancarditis in a patient with coexistent Lyme disease and babesoisis. Ann Intern Med 1985;103:374-6.

22 Steere AC, Malawista SE, Hardin JA, Ruddy S, Askenase PW, Andiman WA. Erythema chronicum migrans and Lyme arthritis: the enlarging clinical spectrum. Ann Intern Med 1977;86:685-98.

23 Steere AC, Brinckerhoff CE, Miller DJ, et al. Elevated levels of collagenase and prostaglandin E2 from synovium associated with erosion of cartilage and bone in a patient with chronic Lyme arthritis. Arthritis Rheum 1980;23:591-9.

24 Johnson YE, Duray PH, Steere AC, et al. Lyme arthritis: spirochetes found in synovial microangiopathic lesions. Am f Pathol 1985;118:26-34.

25 Snydman DR, Schenkein DP, Berardi BP, Lastavica CC, Pariser KM. Borrelia burgdorferi in joint fluid in chronic Lyme arthritis. Ann Intern Med 1986;104:798-800.

26 Craft JE, Grodzicki RL, Steere AC. The antibody response in Lyme disease: evaluation of diagnostic tests. I Infect Dis 1984;149:789-95.

27 Steere AC, Hardin JA, Malowista SE. Erythema chronicum migrans and Lyme arthritis: cryoimmunoglobulins and clinical activity of skin and joint. Science 1977;196:1121-2.

28 Hardin JA, Steere AC, Malawista SE. The pathogenesis of arthritis in Lyme disease: humoral immune responses and the role of intra-articular immune complexes. Yale $\mathcal{f}$ Biol Med 1984;57:589-93.
29 Steere AC, Pachner AR, Malawista SE. Neurological abnormalities of Lyme disease: successful treatment with high-dose intravenous penicillin. Ann Intern Med 1983;99:767-72.

30 Steere AC, Green J, Schoen RT, et al. Successful parenteral penicillin therapy of established Lyme arthritis. $N$ Englf Med 1985;312:869-74.

31 Steere AC, Grodzicki RL, Craft JE, Manesh Shrestha, Kornblatt AN, Malawista SE. Recovery o Lyme disease spirochetes from patients. Yale f Biol Med 1984;57:557-60.

32 Steere AC, Malawista SE, Newman JH, et al. Antibiotic therapy in Lyme disease. Ann Intern Med 1980;93:1-8.

33 Steere AC, Hutchinson GJ, Rahn DW, et al. Treatment of early manifestation of Lyme diseases. Ann Intern Med 1983;99:22-6.

\section{Continued medical education must not be an optional extra}

Clinical tutors working in postgraduate medical centres antedate the paid regional and associate advisers, course organisers, and trainers who run vocational training for general practice. Yet, as Berrington and Varnham report (p 550), general practitioners who are clinical tutors receive little payment and support. Consequently, they cannot devote much time to the important work of continued education - most did only two hours or less a week. This may partly explain why fewer than half of general practitioners attend, or claim expenses for attending, any postgraduate education each year.

Yet general practice is changing fast. Health promotion and the long term care of patients with chronic diseases are becoming much more important, and the number of elderly people in the community is increasing rapidly. New technologies and treatments are being introduced, and new patterns of teamwork are being adopted. At the same time there are increasing demands for economy and accountability, particularly in prescribing, arranging for investigations, and, above all, referring for secondary care. General practitioners will meet these challenges only through new methods of postgraduate education, with performance review as a cornerstone.

The standard of care offered by a doctor is related less to his or her knowledge than to factors that affect its application, ${ }^{2}$ and the most important of these is motivation. Doctors need to know what they are trying to do and how well they are doing it to maintain their enthusiasm; otherwise they develop rituals and their performance declines. ${ }^{3}$ Performance review means setting goals, assessing performance, and receiving and responding to feedback. It is difficult to be both self critical and self confident as a practitioner. Peer review is an opportunity to compare yourself with your colleagues, receive their support, and learn from their ideas, and the process has been shown to produce positive changes in practice. ${ }^{4}$

Performance review can form the basis of a curriculum for continued education but will be useful only if all the important aspects of practice are included and not just those that are easily measured-for instance, record keeping. Current controversies may unfortunately be obscuring the educational value of such powerful approaches as the practice assessment visiting recommended in the Royal College of General Practitioners' report What Sort of Doctor?. ${ }^{5}$ Basing education on the practice diminishes the feeling that it is something separate from work, and working with the whole practice team allows members to learn from each other and increases their commitment to change. ${ }^{6}$ The trend to educate in the practice is growing, ${ }^{7}$ and a range of resources are available to foster it, including distance learning materials and practice facilitators. ${ }^{8}$ 
It is essential that adequate funding is provided to create a network of general practice tutors with the responsibility for developing continued medical education. Their first task will be to assess the local needs of general practices, patients, and the health service and to create a curriculum to meet them. They will need to be able to use proved methods of adult education, particularly small group discussions, and must also become familiar with newer technologies and resources. Finally, they must evaluate the effectiveness of their efforts in producing changes in patient care in practice. ${ }^{9}$ This is no small job, and they will require remunerated time, resources, and training. "With small men," said John Stuart Mill, "no great things can really be accomplished."10

In the past doctors have asked for resources without commitment and the government for commitment without providing resources. Both must now move, and our leaders should not be afraid of saying so. Keeping up to date, reviewing our own performance, and adapting our practice to meet new needs should be regarded as an integral part of our work and not peripheral activities that can be relegated to leisure time or omitted altogether unless extra income is forthcoming. Performance review and practice based education will, however, be fully accepted only when they are clearly seen to increase doctors' professional satisfaction and improve the care of their patients.

\section{T P C SCHOFIELD}

General Practitioner,

Shipston-on-Stour CV36 4BQ, and

Health Education Council Lecturer in General Practice,

Department of Community Medicine and General Practice,

University of Oxford

1 Department of Health and Social Security. Primary health care: an agenda for discussion. London: HMSO, 1986. (Cmnd 9771.)

2 Sanazaro PJ. Determining physicians' performance. Evaluation and the Health Professional 1983;6:197-210.

3 Pendleton DA, Schofield TPC. Motivation and performance in general practice. In: Gray DJP, ed. The medical annual. Bristol: John Wright, 1983.

4 Fleming DM, Lawrence MSTA. Impact of audit on preventive measures. $\mathrm{Br} \mathrm{Med} f$ 1983;287:1852-4.

5 Royal College of General Practitioners. What sort of doctor? London: RCGP, 1985. (Report from General Practice No 23.)

6 Horder J, Bosanquet N, Stocking B. Ways of influencing the behaviour of general practitioners. I R Coll Gen Pract 1986;36:517-21.

7 Reiss BB, Berrington RM, Stuart DRM, Tait IG. Practice educational meetings: a new influence in general practice. $\mathrm{Br}$ Med $\mathcal{F}$ 1981;283:1025-7.

8 Fullard E, Fowler G, Gray JAM. Facilitating prevention in primary care. $\mathrm{Br} \mathrm{Med} f$ 1984;289:1585-7.

9 Haynes RB, Davies DA, McKibbon A, Tugwell D. A critical appraisal of the efficiency of continued medical education. FAMA 1984;251:61-4.

10 Mill JS. Essay on liberty. London: Parker and Son, 1859.

\section{Late abortion}

The Bishop of Birmingham's bill to reduce the limit for abortion from 28 to 24 weeks' gestation has run into sand (21 February, p 523). But the bill may be reintroduced, and doctors need to consider the case for retaining the right to carry out late abortions in exceptional cases.

Anthropological ${ }^{1}$ and archaeological $^{2}$ evidence shows that abortions have been performed for millennia. They are permitted because most societies hold the rights of pregnant women above those of a fetus without personhood. Personhood is acquired in a process that is often taken as beginning at birth. Christian thought has changed over the centuries ${ }^{3}$ : ensoulment at conception was propounded in $1869,{ }^{4}$ but early Christian philosophers thought that personhood began with quickening, ${ }^{4}$ a poorly defined but convenient time. This attitude extends futher: New York State restricted execution of pregnant women to those who had not felt fetal movement. ${ }^{5}$ The Talmud permits child destruction to save the mother until the birth of the head. ${ }^{4}$ Some philosophers ${ }^{46}$ and societies ${ }^{4}$ think that personhood is achieved only after birth.

Defining viability by gestation is a peculiarly British practice. ${ }^{7}$ There is no legal upper limit on abortion in the United Kingdom, but the 1929 Infant Life Preservation Act makes it a criminal offence to cause a child "capable of being born alive" to die and presumes viability at 28 weeks' gestation. The Supreme Court in the United States, starting with Roe $v$ Wade in 1973, has left viability undefined and to be decided by the woman's doctor.

In 1985 only 31 of 141101 abortions on United Kingdom residents were performed after 25 weeks' gestation. ${ }^{9}$ They are now performed only on NHS premises with facilities for neonatal care; private clinics are not licensed to perform them. Intra-amniotic or extra-amniotic prostaglandins are usually used. Hysterotomy is now rarely performed, but some centres use dilatation and evacuation. ${ }^{10}$ At 24 weeks' gestation the 50th centile for weight is $740 \mathrm{~g}$; at 28 weeks it is 1120 g. ${ }^{11}$ A good neonatal nursery would expect $74 \%$ survival at 28 weeks for babies born in optimal condition ${ }^{12}$; survival at 24 weeks is less common.

A late abortion carries more risks for the woman than an early one. Women may seek a late abortion because they did not realise that they were pregnant or after earlier denial of pregnancy. ${ }^{10}$ One analysis suggested that the delay resulted from a lack of familiarity with pregnancy symptoms and a low expectation of pregnancy because of infrequent intercourse, contraceptive practice, or menstrual irregularity. ${ }^{13}$ This explains why requests for late abortion are commoner at the extremes of reproductive life.$^{10}$ Recommending abortion for these women can be seen as realistic or paternalistic; with assistance perhaps they could cope.

In 1984 the Royal College of Obstetricians and Gynaecologists published its survey of late abortions ${ }^{10}: 39 \%$ of women having an abortion between 20 and 27 weeks of gestation recognised pregnancy late, menstrual irregularity being responsible in $12 \%$ and denial in $13 \%$ of the original sample. Delay caused by doctors was uncommon, but there was probably some selection before the consultation with a gynaecologist.

Any abortion can fail,${ }^{14}$ and in the 1984 survey $0.5 \%$ of requests for a late abortion followed an earlier attempt at termination..$^{10}$ Live birth can follow late termination; prostaglandins take time to work, ${ }^{15}$ although intra-amniotic hypertonic solutions are often used to produce fetal death.

In $1985,7 \cdot 4 \%$ of abortions after 20 weeks' gestation were performed under the section of the Abortion Act dealing with fetal abnormality. Few would have resulted in an abnormal infant: for many women the possibility of abnormality-for example, because of maternal age-was used together with another reason. The advent of chorionic villus sampling, ${ }^{16}$ umbilical blood sampling, ${ }^{17}$ and placental biopsy ${ }^{18}$ should lead to earlier diagnosis of abnormality; $3 \%$ of amniocentesis results were not reported until 24 weeks or later in 1982.? Some metabolic abnormalities and anatomical malformations do not become obvious until late in pregnancy. No abortions have yet been reported in Britain because of maternal infection with the human immunodeficiency virus, but they are inevitable-and the long incubation period may make them late ones. ${ }^{19}$

Opposition to change comes from those who fear the start of restrictive laws and the reduced availability of abortion even for those below 24 weeks because most gynaecologists use a lower margin than permitted. One study has suggested 